\title{
The conservation status of mammals and avifauna in the Montagne des Français massif, Madagascar
}

\author{
Jeremy Sabel ${ }^{\dagger}$, Katie Green', Jeffrey Dawson', Janine \\ Robinson', Charlie Gardner', Georgina Starkie' and \\ Neil D'Cruze"
}

\author{
Correspondence: \\ Jeremy Sabel \\ ecosulis Itd, \\ The Rickyard, Newton St Loe, Bath, BA2 9BT, U.K. \\ E-mail: jeremysabel@gmail.com
}

\begin{abstract}
The Montagne des Français is a limestone massif in northern Madagascar, which is characterised by a wide range of biotopes including xerophytic karst, gallery forest, dry western forest, grassland and caves. It is situated only $12 \mathrm{~km}$ from the regional capital, Antsiranana, and few, if any areas of primary forest remain. In the first comprehensive study to have been carried out at this location we report the presence of 12 mammal species. We also report the presence of 63 bird species. We use data derived from both structured and semi-structured interviews to assess the conservation status of the mammals and birds within the massif. Our study shows that local beliefs are dominated by taboos or fady and that these vary within families and communities. Current anthropogenic pressures on biodiversity include zebu grazing, charcoal production, hunting and rice cultivation. The massif was afforded Temporary Protected Area Status in 2006 and our results suggest that this protection should be made permanent. We propose opportunities for further research and sustainable development initiatives that could contribute to the conservation of the biological resources within the massif. Success in conserving this area will only be achieved if the local communities are fully engaged.
\end{abstract}

\section{RÉSUMÉ}

La Montagne des Français est un massif calcaire au nord de Madagascar, caractérisé par une vaste gamme de biotopes, y compris une formation calcaire connue localement sous le nom de 'tsingy' avec une végétation xérophyte, une forêt riveraine, une forêt sèche de l'ouest, des zones herbeuses et des grottes. Elle se trouve à $12 \mathrm{~km}$ seulement de la plus grande ville du nord, Antsiranana, et présente une couverture de forêts intactes extrêmement réduite. Le travail sur le terrain a été réalisé par des bénévoles de Frontier et des chercheurs de Frontier et de I'Université d'Antsiranana. Des inventaires on été effectués pendant une année, au cours de quatre périodes d'essais qui s'étalaient chacune sur une durée de l'ordre de neuf semaines. Les inventaires sur les mammifères ont fait appel à trois méthodes, dont les lignes de trous-pièges, l'emploi de pièges Sherman et des recherches nocturnes aléatoires. Un inventaire sur les oiseaux a été compilé, utilisant la technique de la liste de recensement McKinnon.

Au cours de cette première étude détaillée portant sur cette localité, nous avons relevé la présence de 12 espèces de mammifères ainsi que la présence de 63 espèces d'oiseaux. Neuf des espèces de mammifères recensés sontendémiquesà Madagascar et la plupart de ces espèces semblaient être représentées par des effectifs réduits sur la Montagne des Français au cours de la période d'étude. De toutes les espèces d'oiseaux reportées, $26(41 \%)$ sont endémiques de Madagascar.

Afin d'évaluer l'état de conservation des mammifères et des oiseaux rencontrés à la Montagne des Français, nous avons utilisé des données recueillies au cours d'entrevues formelles et semi-formelles. Notre étude montre que les croyances locales sont dominées par des tabous ou fady et que ceux-ci varient selon les familles et communautés. Les pressions anthropogéniques actuelles qui pèsent sur la biodiversité sont représentées par le pâturage des zébus, la production de charbon de bois, la chasse et la culture de riz. En 2006 le massif a bénéficié d'un statut d’Aire Protégée Temporaire mais nos résultats suggèrent qu'un statut de protection permanente serait justifié. Nous proposons de poursuivre les efforts en matière de recherche et encourageons toute entreprise de développement durable qui pourrait contribuer à la conservation des ressources biologiques à l'intérieur du massif. La réussite de la protection de cette région ne pourra se faire sans la totale adhésion de l'ensemble des communautés locales.

KEYWORDS: Biodiversity, Endemism, Conservation priority areas, Montagne des Français.

MOTS CLEF: biodiversité, endémisme, aires protégées prioritaires, Montagne des Français.

\section{INTRODUCTION}

The Montagne des Français massif is situated in northern Madagascar and lies within the western dry forest domain (Humbert and Cours Darne 1965). The massif covers an area of approximately 6,114 ha and altitudes range between 


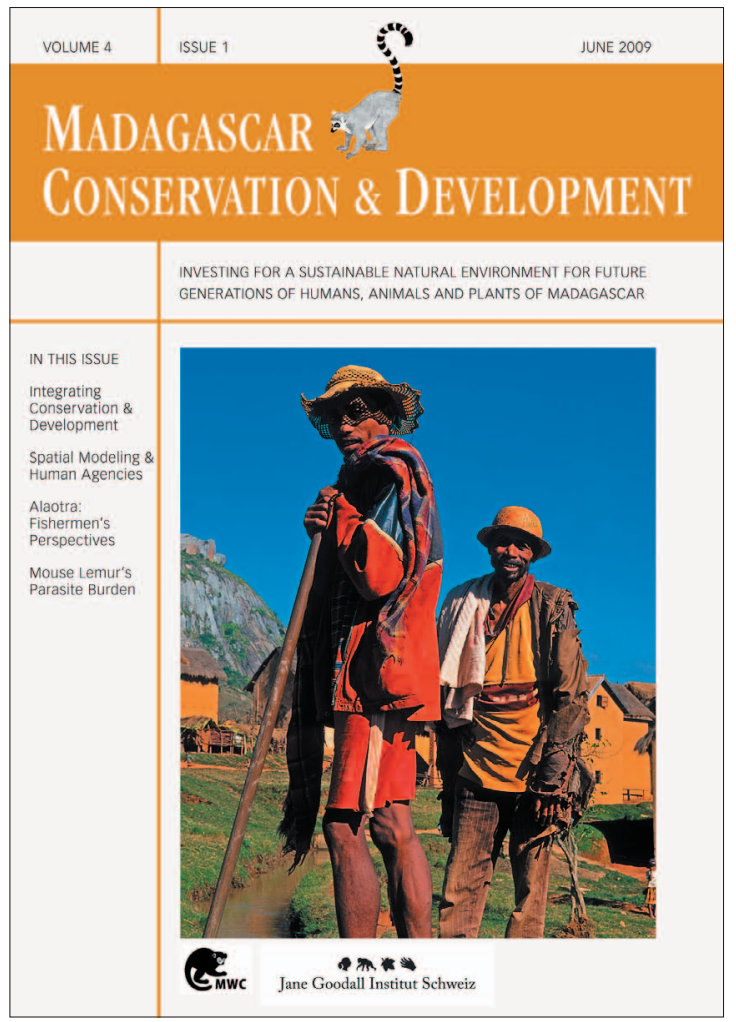

Madagascar Conservation \& Development is the journal of Madagascar Wildlife Conservation (MWC) and the Jane Goodall Institute (JGI Switzerland). It is produced in these institutions' own responsibility.

All the Issues and articles are freely available at http://www.mwc-info.net/en/services/journal.htm

Contact Journal MCD

info@journalmcd.net for general inquiries MCD funding@journalmcd.net for supporting the journal

Journal Madagascar Conservation \& Development Institute and Museum of Anthropology University of Zurich

Winterthurerstrasse 190

$\mathrm{CH}-8057$ Zurich, Switzerland

contact@mwc-info.net for general inquiries

Postfach 2701

CH-8021 Zürich, Switzerland

Logement 11, Cité Andohaniato Antananarivo 101, Madagascar

info@janegoodall.ch for general inquiries JGI

$2 \pi \approx$

Jane Goodall Institut Schweiz
Jane Goodall Institute Schweiz

Postfach 2807

8033 Zürich

Switzerland 
$100 \mathrm{~m}$ and $400 \mathrm{~m}$. As a result, its vegetation is of a more mesic type than that of its surroundings, and has been described as transitional between mid-altitude rainforest and dry deciduous western forest (Ramanamanjato et al. 1999).

Due to its elevation, the average annual precipitation at Montagne des Français is usually higher than that received by Antsiranana $12 \mathrm{~km}$ to the northwest. Antsiranana receives a mean annual rainfall of $915 \mathrm{~mm}$ with nine months of the year being dry (Cornet 1974). The narrow annual temperature variation $\left(3.2^{\circ} \mathrm{C}\right)$ is characteristic of sub-equatorial regions.

In the massif, few if any areas of primary forest remain. Most areas of forest are disturbed to some degree by agriculture and/or zebu grazing. The massif is surrounded by grassland, scrub and agricultural land, and is as a consequence, isolated from other major areas of forest in the extreme north of Madagascar (Ankarana, Analamera and Montagne d'Ambre). It has been suggested that anthropogenic deforestation is responsible for the isolation of the massif (Ramanamanjato et al. 1999) and this is unsurprising due to its position close to the provincial capital of Antsiranana.

Like many parts of Madagascar, local beliefs are dominated by taboos or fady. In the villages surrounding the Montagne des Français a significant proportion of the population consider it fady to kill lemurs but our study shows that fady varies within families and communities. This may in part be because some residents in the area come from as far as $750 \mathrm{~km}$ away.

In 2006 Montagne des Français was nominated as a Durban Vision Potential Site requiring some form of protection (Ministère de I'Environment, des Eaux et Forêts 2005) and was granted Temporary Protected Area Status (the first of three steps necessary to create a permanently protected area). Prior to this, the massif was afforded minimal official protection, which means that the exploitation of biological resources proceeded unregulated. The objectives of this article are to:

1. Highlight the biological importance of Montagne des Français;

2. Support the case for permanent protection;

3. Suggest ways in which further research and initiatives could enhance conservation of the biological resources within the massif.

\section{METHODS}

Researchers and volunteers from Frontier and the University of Antsiranana carried out fieldwork; surveys were conducted over the course of a year in four sampling periods each lasting approximately nine weeks: 7 April-15 June 2005, 28 June5 September 2005, 5 October-14 December 2005 and 3 January7 March 2006. Sampling periods coincided with the availabilty of volunteers to assist with the surveys. The base camp was located at $\mathrm{E} 49^{\circ} 22.05^{\prime}, \mathrm{S} 12^{\circ} 19.68^{\prime}$, close to the village of Andavakoera and adjacent to a reliable water source. The core survey area covered an area of approximately 600 ha in the immediate environs of the base camp (Figures 1 and 2).

MAMMALIAN SURVEY. Three survey methods were used:

1. Pitfall trapping. Regular deployment of pitfall traps consisting of 11 buckets $270 \mathrm{~mm}$ deep and $290 \mathrm{~mm}$ in diameter were sunk into the ground at $10 \mathrm{~m}$ intervals along a transect of $100 \mathrm{~m}$. Generally three transects were installed at a time and checked concurrently, and each line was duplicated at three different seasons. Small holes were punched into the bottom

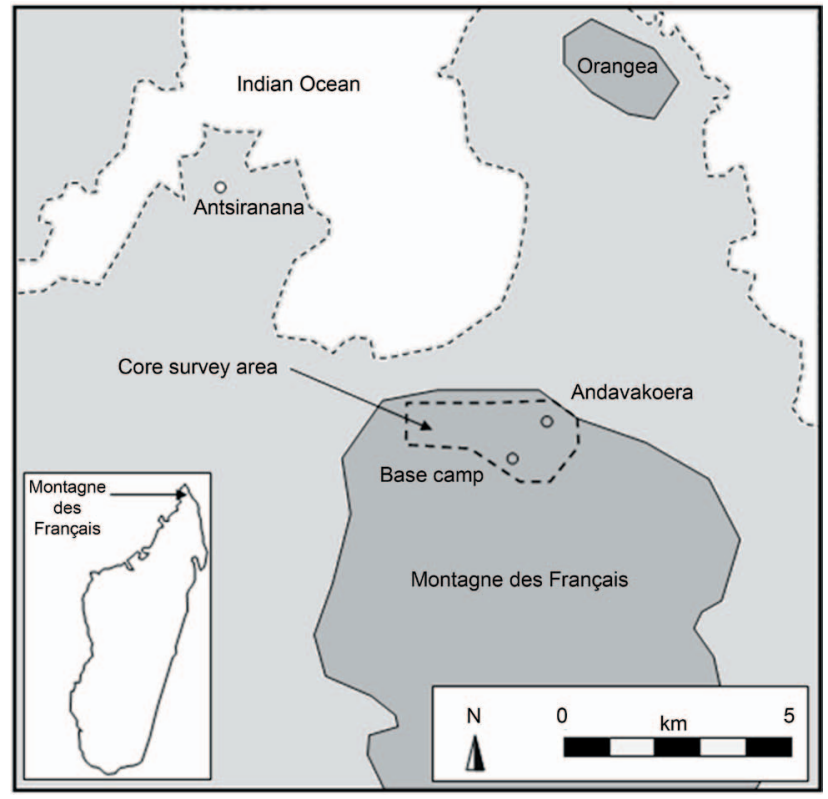

FIGURE 1. Map showing the core survey area.

of each bucket to allow water to drain. A plastic drift fence $0.5 \mathrm{~m}$ high was tied to thin wooden stakes and buried into the ground such that it ran across the diameter of each pitfall trap along the length of the transect. Transects were checked every morning and afternoon for a 7-8 day period. Captures were uniquely marked (by clipping fur) and released at the point of capture. A total of 12 lines duplicated three times made 36 transects carried out during the survey period in either forest or disturbed habitat.

2. Sherman trapping. Associated with each of the above transects, six sherman traps were installed as follows; two or three traps were placed in trees whilst the remainder were placed on the ground. Traps were baited with banana or peanut butter during the evening and checked for captures the following morning. Again, captures were uniquely marked and released at the point of capture. A 'trap-day' is defined as a 24 -hour period (dawn to dawn) of one trap in use. A total of 1,620 trap-days were undertaken during the entire survey period and traps were in place at each location for 7-8 days (Stephenson 1994).

3. Nocturnal searches. Regular nocturnal mammal searches were undertaken using high power torches along two footpaths starting from the base camp and ending at either E49 $21.27^{\prime}$, $\mathrm{S} 12^{\circ} 19.41^{\prime}$ or $\mathrm{E} 49^{\circ} 20.21^{\prime}, \mathrm{S} 12^{\circ} 20.12^{\prime}$. These footpaths did not coincide with any of the transects and the searches totalled 50 hours throughout the study period.

4. Incidental records. Mammal species that were observed but were not recorded using the methods above were noted as incidental observations. Nomenclature of mammals follows Goodman et al. (2003).

AVIAN SURVEY. A bird species list was compiled for

Montagne des Français using the Mackinnon list census technique (Mackinnon and Phillipps 1993). A total of 110 Mackinnon lists were conducted during the study period using existing trails at dawn and dusk. The Mackinnon list method was chosen as it is recommended as a rapid assessment technique that is less susceptible to observer bias than other bird census techniques (O'Dea et al. 2004). This was important for this study as a team of researchers accompanied by varying teams of 
volunteers carried out the fieldwork. The observers record a pre-determined number of species to complete one list. Thus, the unit of effort is the completion of one list. Many studies use a 10-species species list as this provides the most accurate results in species poor environments (Herzog et al. 2002, Trainor 2002, Watson et al. 2005). Species lists consisting of ten species were carried out in this study as the composition of species in the area was unknown and Malagasy avifauna is known to be relatively species poor with only 209 breeding species (Hawkins and Goodman 2003). Identification was confirmed by observation of the species; vocalizations were only used to aid observations and identification. Bird species that were observed but were not recorded using the Mackinnon list technique were noted as incidental observations. Nomenclature of birds follows Hawkins and Goodman (2003).

SOCIOECONOMIC SURVEY. A total of 25 structured interviews were carried out with residents involved in hunting from the village of Andavakoera (E49 $21.31^{\prime}, \mathrm{S} 12^{\circ} 20.02^{\prime}$ ) situated on the lower slopes of the massif (Figure 1). Interviewees were presented with a list of mammals and birds in Malagasy accompanied by photos and were asked to comment on their presence in the Montagne des Français. This list included species that had not been recorded by our study. Interviewees were all male residents of Andavakoera and ranged in age from 19 to 78 years.

In addition, 18 semi-structured interviews were undertaken with residents of the massif and Andavakoera to gain an understanding of the impacts of hunting, zebu grazing, charcoal burning and other anthropogenic activities on wildlife habitat and populations. These interviews were conducted with different people to those who answered the structured interviews. Nine of the interviewees lived within the massif but several had moved to the area from other parts of Madagascar: Ambilobe $\left(100 \mathrm{~km}, \mathrm{E} 49^{\circ} 03.03^{\prime}, \mathrm{S} 13^{\circ}\right.$ $\left.11.45^{\prime}\right)$, Vohemar $\left(150 \mathrm{~km}, \mathrm{E} 50^{\circ} 00.21^{\prime}, \mathrm{S} 13^{\circ} 21.15^{\prime}\right)$, Maroantsetra

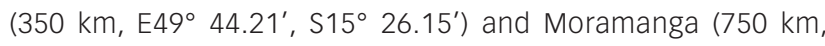
$\left.\mathrm{E} 48^{\circ} 13.21^{\prime}, \mathrm{S} 18^{\circ} 56.51^{\prime}\right)$. Five women and thirteen men were interviewed with an age range from 25-75 years.

\section{RESULTS}

MAMMALS. A total of 12 mammal species were recorded in the massif during the study period (Tables 1 and 2). Three species are not native but have been introduced to Madagascar by humans, namely Black rat (Rattus rattus), Pygmy musk shrew

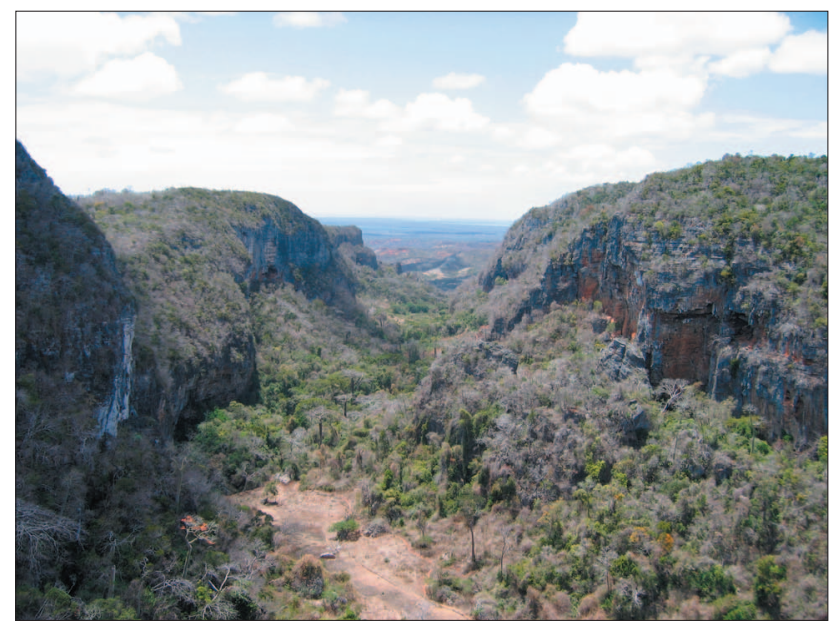

FIGURE 2. View of the canyon in the core survey area. (c) Jeremy Sabel
(Suncus madagascariensis) and House mouse (Mus musculus). The remaining nine species are endemic to Madagascar whilst three of these are endemic to northern Madagascar, namely Crowned lemur (Eulemur coronatus), Northern rufous mouse lemur (Microcebus tavaratra) and Northern sportive lemur (Lepilemur septentrionalis). The most recent assessment of the conservation status of lemurs (Mittermeier et al. 2006) lists Aye-aye (Daubentonia madagascariensis) and Crowned lemur (Eulemur coronatus) as vulnerable, Northern rufous mouse lemur (Microcebus tavaratra) as Endangered and Northern sportive lemur (Lepilemur septentrionalis) as Critically Endangered. The four lemur species are also listed in CITES Appendix I.

Two of the mammal species could only be identified down to the level of genus (Eliurus sp. and Microgale sp.). Many of the species encountered appeared to be present in very low numbers as sightings and / or captures over the entire study period were rare (Table 1). There were no sightings of Fat-tailed dwarf lemur (Cheirogaleus medius) although it has been noted in the area (Mittermeier et al. 2006).

BIRDS. A total of 63 bird species were recorded in the massif over the study period including the Madagascar crested ibis (Lophotibis cristata), which is listed as Near Threatened on the IUCN Red Data List 2007 (Table 3). Of the 63 species, $26(41 \%)$ are endemic to Madagascar.

SOCIOECONOMIC SURVEY. Structured interviews:

All of the interviewees recognised the presence of the Crowned lemur (Eulemur coronatus) in Montagne des Français. Only $8 \%$ of the interviewees acknowledged the existence of the Aye-aye (Daubentonia madagascariensis) and $40 \%$ the Northern sportive lemur (Lepilemur septentrionalis) in the massif, respectively. None of the interviewees knew of the presence of the Northern rufous mouse lemur (Microcebus tavaratra). All of these latter species are cryptic and nocturnal and most locals do not spend time in the forest at night, which could explain the lack of knowledge. The only carnivore observed during the study period was the Ring-tailed mongoose (Galidia elegans), and $64 \%$ of the interviewees agreed with the existence of this species.

Interviewees described the presence of three mammal species not recorded during the study. All but one of the interviewees (96\%) stated that the Grey bamboo lemur (Hapalemur griseus) is present within the massif whilst $56 \%$ and $52 \%$ respectively stated that Indian civet (Viverricula indica) and Fosa (Cryptoprocta ferox) are present.

Semi-structured interviews: A great majority (89\%) of interviewees were involved in arable farming, whilst $28 \%$ were pastoralists (mainly zebu cattle). Most interviewees (78\%) stated that they hunt a wide variety of animals and the remainder of interviewees contribute indirectly to demand by purchasing meat. Half of the interviewees hunt Tenrec (Tenrec ecaudatus) and Greater hedgehog tenrec (Setifer setosus); $28 \%$ hunt Madagascar crested ibis (Lophotibis cristata); $11 \%$ hunt Crowned lemurs (Eulemur coronatus) and $6 \%$ hunt Ring-tailed mongoose (Galidia elegans). All these species are listed on the 2007 Red List of Threatened Species. Seventeen percent of interviewees hunt African wild pig (Potamochoerus larvatus); however, this species was not seen during the course of the study period.

The interviewees that hunt lemurs stated that they did so using catapults and noose traps. African wild pig and Indian civet are hunted by 3-4 men at a time using spears, dogs and 
TABLE 1. Capture results of small mammals obtained in pitfall lines and Sherman traps, with additional observations (* denotes native species; numbers within brackets for animals observed but not captured).

\begin{tabular}{|c|c|c|c|c|c|c|c|c|c|c|c|}
\hline \multicolumn{2}{|c|}{ Location of trapline } & \multirow[t]{2}{*}{ Period } & \multirow[b]{2}{*}{$\begin{array}{l}\frac{0}{\pi} \\
0 \\
\frac{0}{0} \\
\frac{0}{\Sigma} \\
\dot{2}\end{array}$} & \multirow[b]{2}{*}{ 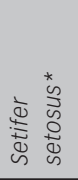 } & \multirow[b]{2}{*}{ 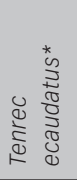 } & \multirow[b]{2}{*}{ 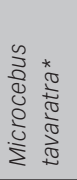 } & \multirow[b]{2}{*}{ 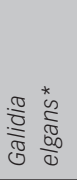 } & \multirow[b]{2}{*}{ 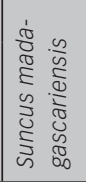 } & \multirow[b]{2}{*}{ 咅 ${ }^{*}$} & \multirow[b]{2}{*}{ 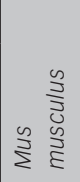 } & \multirow[b]{2}{*}{ 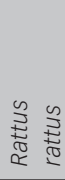 } \\
\hline Habitat & $\begin{array}{l}\text { Longitude, } \\
\text { Latitude, } \\
\text { Altitude }\end{array}$ & & & & & & & & & & \\
\hline $\begin{array}{l}\text { Canyon, } \\
\text { disturbed }\end{array}$ & $\begin{array}{l}\mathrm{E} 49^{\circ} 20.54^{\prime}, \\
\mathrm{S} 12^{\circ} 19.72^{\prime}, \\
195 \mathrm{~m}\end{array}$ & 17-24 IV 2005 & & & & & & 1 & & & 1 \\
\hline $\begin{array}{l}\text { Canyon, } \\
\text { disturbed }\end{array}$ & $\begin{array}{l}\mathrm{E} 49^{\circ} 20.62^{\prime}, \\
\mathrm{S} 12^{\circ} 19.77^{\prime}, \\
195 \mathrm{~m}\end{array}$ & 17-24 IV 2005 & & & & & & 1 & & & \\
\hline \multirow{2}{*}{$\begin{array}{l}\text { Canyon, } \\
\text { disturbed }\end{array}$} & \multirow{2}{*}{$\begin{array}{l}\mathrm{E} 49^{\circ} 20.62^{\prime}, \\
\mathrm{S} 12^{\circ} 19.80^{\prime}, \\
195 \mathrm{~m}\end{array}$} & 17-24 IV 2005 & & 1 & & & & 1 & & & 1 \\
\hline & & $6-15$ XI 2005 & & & & & & & & & 6 \\
\hline \multirow{4}{*}{$\begin{array}{l}\text { Steep hillside, } \\
\text { forest }\end{array}$} & \multirow{4}{*}{$\begin{array}{l}\mathrm{E} 49^{\circ} 21.27^{\prime}, \\
\mathrm{S} 12^{\circ} 20.24^{\prime}, \\
170 \mathrm{~m}\end{array}$} & 26 IV-3 V 2005 & & & & & & 5 & & & 2 \\
\hline & & 6-14 VII 2005 & & & & & & & & & 1 \\
\hline & & $15-24 \times 2005$ & & & & & & & & & \\
\hline & & $10-19$ | 2006 & & & 1 & & & & & 1 & \\
\hline \multirow{4}{*}{$\begin{array}{l}\text { Steep hillside, } \\
\text { forest }\end{array}$} & \multirow{4}{*}{$\begin{array}{l}\mathrm{E} 49^{\circ} 21.23^{\prime}, \\
\mathrm{S} 12^{\circ} 20.27^{\prime}, \\
185 \mathrm{~m}\end{array}$} & 26 IV-3 V 2005 & & & & & & & & & \\
\hline & & 6-14 VII 2005 & & & & & & 2 & & & 1 \\
\hline & & $15-24 \times 2005$ & & & & & & 1 & & & \\
\hline & & $10-19$ | 2006 & & & & & & & & & 2 \\
\hline \multirow{4}{*}{$\begin{array}{l}\text { Slight hillside, } \\
\text { forest }\end{array}$} & \multirow{4}{*}{$\begin{array}{l}\mathrm{E} 49^{\circ} 21.18^{\prime}, \\
\mathrm{S} 12^{\circ} 20.27^{\prime} \\
185 \mathrm{~m}\end{array}$} & 26 IV-3 V 2005 & & & & (1) & & & & & 1 \\
\hline & & 6-14 VII 2005 & & & & & & & & & \\
\hline & & $15-24 \times 2005$ & & & & & & 1 & & 1 & 3 \\
\hline & & $10-19$ | 2006 & & & & & & 1 & & & \\
\hline \multirow{2}{*}{$\begin{array}{l}\text { Valley, } \\
\text { forest }\end{array}$} & \multirow{2}{*}{$\begin{array}{l}\mathrm{E} 49^{\circ} 21.44^{\prime}, \\
\mathrm{S} 12^{\circ} 20.86^{\prime}, \\
82 \mathrm{~m}\end{array}$} & 26 V-2 VI 2005 & & & & & & 1 & & 1 & 6 \\
\hline & & $19-28$ XI 2005 & & & & & (1) & 3 & & & 3 \\
\hline \multirow{2}{*}{$\begin{array}{l}\text { Slight hillside, } \\
\text { forest }\end{array}$} & \multirow{2}{*}{$\begin{array}{l}\mathrm{E} 49^{\circ} 21.44^{\prime}, \\
\mathrm{S} 12^{\circ} 20.97^{\prime}, \\
79 \mathrm{~m}\end{array}$} & 26 V-2 VI 2005 & & & & & & 2 & & 1 & 8 \\
\hline & & $19-28$ XI 2005 & & & & & & & & & 4 \\
\hline Slight hillside, & $\mathrm{E} 49^{\circ} 21.48^{\prime}$ & 26 V-2 VI 2005 & 1 & & & & (1) & & 1 & & 5 \\
\hline & $\begin{array}{l}\mathrm{S} 12^{\circ} 21.09^{\prime}, \\
90 \mathrm{~m}\end{array}$ & $19-28$ XI 2005 & & & & & & & & & 1 \\
\hline Gully, forest & $\mathrm{E} 49^{\circ} 20.60^{\prime}$ & 29 VII-6 VIII 2005 & & & & & & & & 1 & 4 \\
\hline & $\begin{array}{l}\mathrm{S} 12^{\circ} 19.59^{\prime}, \\
232 \mathrm{~m}\end{array}$ & $22-31$ I 2006 & & & & & & 2 & & & \\
\hline Slight hillside, & E49 20.59', & 29 VII-6 VIII 2005 & & & & & & & & 2 & 6 \\
\hline & $\begin{array}{l}\mathrm{S} 12^{\circ} 19.64^{\prime}, \\
262 \mathrm{~m}\end{array}$ & $22-31 \mid 2006$ & & & 1 & & & & & & \\
\hline Steep hillside, & E49⒛53', & 29 VII-6 VIII 2005 & & & & & & 1 & & & 2 \\
\hline forest & $\begin{array}{l}\mathrm{S} 12^{\circ} 19.63^{\prime}, \\
288 \mathrm{~m}\end{array}$ & $22-31$ I 2006 & & 1 & & & & & & 1 & \\
\hline Gully, & E49 20.7' & 11-20 VIII 2005 & 1 & & & & & & & & 5 \\
\hline disturbed & $\begin{array}{l}\mathrm{S} 12^{\circ} 19.58^{\prime}, \\
291 \mathrm{~m}\end{array}$ & $3-12$ || 2006 & & & & & & 1 & & & 2 \\
\hline Slight hillside, & $\mathrm{E} 49^{\circ} 20.22^{\prime}$ & 11-20 VIII 2005 & & & & & & & & & 4 \\
\hline forest & $\begin{array}{l}\mathrm{S} 12^{\circ} 19.72^{\prime}, \\
318 \mathrm{~m}\end{array}$ & 3-12 II 2006 & & & & & & & & 2 & 3 \\
\hline Slight hillside, & E49 $20.23^{\prime}$, & 11-20 VIII 2005 & & & & & & 1 & & & 1 \\
\hline forest & $\begin{array}{l}\mathrm{S} 12^{\circ} 19.68^{\prime}, \\
314 \mathrm{~m}\end{array}$ & 3-12 || 2006 & & & & & & 1 & & & 1 \\
\hline $\begin{array}{l}\text { Canyon, } \\
\text { disturbed }\end{array}$ & $\begin{array}{l}\mathrm{E} 49^{\circ} 20.56^{\prime}, \\
\mathrm{S} 12^{\circ} 19.81^{\prime}, \\
195 \mathrm{~m}\end{array}$ & 6-15 XI 2005 & & & & & & & & & 2 \\
\hline $\begin{array}{l}\text { Canyon, } \\
\text { disturbed }\end{array}$ & $\begin{array}{l}\mathrm{E} 49^{\circ} 20.51^{\prime}, \\
\mathrm{S} 12^{\circ} 19.85^{\prime}, \\
195 \mathrm{~m}\end{array}$ & 6-15 XI 2005 & & & & & & 1 & & & 3 \\
\hline Total number o & & & 2 & 2 & 2 & - & - & 26 & 1 & 10 & 78 \\
\hline Total number o & d observed & & 2 & 2 & 2 & 1 & 2 & 26 & 1 & 10 & 78 \\
\hline
\end{tabular}


TABLE 2. Mammals recorded in Montagne des Français and not associated with pitfall lines or Sherman traps.

\begin{tabular}{|c|c|c|c|c|c|c|}
\hline \multirow[t]{2}{*}{ Taxa } & \multicolumn{4}{|c|}{ Incidental observation, at $\mathrm{E} 49^{\circ} 22.05^{\prime}, \mathrm{S} 12^{\circ} 19.68^{\prime}$} & \multicolumn{2}{|c|}{ Nocturnal search at $\mathrm{E} 49^{\circ} 21.18^{\prime}, \mathrm{S} 12^{\circ} 19.55^{\prime}$} \\
\hline & 7 IV-15 VI 2005 & 28 VI-5 IX 2005 & 5 X-14 XII 2005 & $3 \mid-7$ III 2006 & $5 X-14$ XII 2005 & 3 |-7 III 2006 \\
\hline \multicolumn{7}{|l|}{ O. Afrosoricida } \\
\hline \multicolumn{7}{|l|}{ Tenrecidae } \\
\hline Setifer setosus & 8 & & 3 & 8 & & \\
\hline Tenrec ecaudatus & & & 8 & 22 & & \\
\hline \multicolumn{7}{|l|}{ O. Primata } \\
\hline \multicolumn{7}{|l|}{ Cheirogaleidae } \\
\hline Microcebus tavaratra & 2 & 2 & 1 & 1 & & \\
\hline \multicolumn{7}{|l|}{ Lemuridae } \\
\hline Eulemur coronatus & 23 & 27 & 13 & 21 & & \\
\hline \multicolumn{7}{|l|}{ Megalapidae } \\
\hline Lepilemur septentrionalis & & & & & 2 & 2 \\
\hline \multicolumn{7}{|l|}{ Daubentoniidae } \\
\hline Daubentonia madagascariensis & & & & 1 & & \\
\hline \multicolumn{7}{|l|}{ O. Carnivora } \\
\hline \multicolumn{7}{|l|}{ Eupleridae } \\
\hline Galidia elegans & 1 & & 1 & 1 & & \\
\hline \multicolumn{7}{|l|}{ O. Rodentia } \\
\hline \multicolumn{7}{|l|}{ Nesomyidae } \\
\hline Eliurus sp. & 1 & & & & & \\
\hline Total number of species observed & 5 & 2 & 5 & 6 & 1 & 1 \\
\hline
\end{tabular}

wooden traps. Tenrecs are hunted by 1-2 people and dogs; hunting ceases in January when the tenrecs produce young. Birds are hunted using nooses, catapults and nets. One interviewee stated that he caught parrots by using maize as bait and placing glue on the perch and another stated that he uses poisoned maize to kill parrots and Madagascar crested ibis and takes care to remove the stomach.

Half of the interviewees stated that it is fady to kill African wild pig (Potamochoerus larvatus) whereas $44 \%$ stated that it is fady to kill Crested drongo (Dicrurus forficatus), Pied crow (Corvus albus) and owls. In addition a third of interviewees stated that it is fady to kill lemurs.

The majority of interviewees $(72 \%)$ stated that they harvest wood from the massif and $22 \%$ sell it for profit, mostly in Antsiranana. A similar number (78\%) of interviewees stated that they are involved in charcoal production and $67 \%$ sell it for financial gain.

\section{DISCUSSION}

Within the Montagne des Français lemur species benefit from the belief among some locals that it is fady to kill lemurs. Neither the Aye-aye (Daubentonia madagascariensis), the Northern sportive lemur (Lepilemur septentrionalis) nor the Northern rufous mouse lemur (Microcebus tavaratra) appear to be hunted and few of the interviewees knew of their existence within Montagne des Français.

The Northern sportive lemur (Lepilemur septentrionalis) is considered Critically Endangered by Mittermeier et al. (2006). This genus is among the most hunted lemurs in Madagascar (Olivieri et al. 2005, Scheumann et al. 2007) due to its conspicuous sleeping sites and its tendency to hide rather than flee when disturbed. The Northern rufous mouse lemur
(Microcebus tavaratra) is considered Endangered by Mittermeier et al. (2006). This species was described in 2000 by Rasoloarison et al., and has a highly clumped distribution.

Crowned lemur (Eulemur coronatus) were recorded frequently during the study period, perhaps due to its diurnal habits and tendency to give alarm calls. In addition a third of interviewees (33\%) stated that it is fady to kill lemurs. Therefore, we conclude that hunting pressure seems to be low for the crowned lemur (Eulemur coronatus, classified as Vulnerable by Mittermeier et al. (2006)).

Northern sportive lemur (Lepilemur septentrionalis), Northern rufous mouse lemur (Microcebus tavaratra) and Crowned lemur (Eulemur coronatus) all have highly clumped distributions in the northern part of Madagascar and are protected only in Montagne d'Ambre National Park and Ankarana, Analamera, and Forêt d'Ambre Special Reserves. Habitat loss and fragmentation is of particular concern for the Aye-aye (Daubentonia madagascariensis) because it has a large home range and low natural population densities compared to other lemurs (Mittermeier et al. 2006). This species occurs in numerous protected areas in Madagascar but has been assessed as being Vulnerable by Mittermeier et al. (2006).

of the nine endemic species of mammal recorded during the study period, six were encountered on less than ten occasions during the study period and we consider that these species (Aye-aye Daubentonia madagascariensis, Northern sportive lemur Lepilemur septentrionalis, Northern rufous mouse lemur Microcebus tavatra, Ring-tailed mongoose Galidia elegans, Tuft-tailed rat Eliurus sp. and Shrew tenrec Microgale sp.), in addition to the Crowned lemur (Eulemur coronatus) are of conservation importance in the Montagne des Français. When combined with the eight species of bats recorded 
TABLE 3: Species list of the avifauna observed in the Montagne des Français.

Abbreviations: Status (Hawkins \& Goodman 2003). B=Breeding, I=Introduced, M=Migrant and E = endemic * $=$ listed as near threatened on the IUCN Red Data List 2007. CITES I = listed in Appendix 1, II = Listed in Appendix 2

\begin{tabular}{|c|c|c|c|c|c|c|c|}
\hline Vernacular name & Scientific name & Status & CITES & Vernacular name & Scientific name & Status & CITES \\
\hline Squacco heron & Ardeola ralloides & B & & \multirow{2}{*}{$\begin{array}{l}\text { Madagascar } \\
\text { paradise flycatcher }\end{array}$} & \multirow[t]{2}{*}{ Terpsiphone mutata } & \multirow[t]{2}{*}{ B } & \\
\hline Cattle egret & Bubulcus ibis & B & & & & & \\
\hline Madagascar crested ibis* & Lophotibis cristata & $E$ & & Souimanga sunbird & Nectarinia souimanga & B & \\
\hline Fulvous whistling duck & Dendrocygna bicolor & $B$ & & Long-billed green sunbird & Nectarinia notata & $\mathrm{B}$ & \\
\hline Yellow-billed kite & Milvus aegyptius & B & & \multirow[t]{2}{*}{ Madagascar white-eye } & \multirow{2}{*}{$\begin{array}{l}\text { Zosterops } \\
\text { maderaspatana }\end{array}$} & \multirow[t]{2}{*}{ B } & \\
\hline Madagascar harrier-hawk & Polyboroides radiatus & $E$ & $\|$ & & & & \\
\hline Frances's sparrowhawk & Accipiter francesii & B & ॥ & Red-tailed vanga & $\begin{array}{l}\text { Calicalicus } \\
\text { madagascariensis }\end{array}$ & E & \\
\hline Madagascar buzzard & Buteo brachypterus & $E$ & II & Hook-billed vanga & \multirow{2}{*}{ Vanga curvirostris } & E & \\
\hline Madagascar kestrel & Falco newtoni & B & $\|$ & \multirow{2}{*}{$\frac{\text { Sickle-billed vanga }}{\text { Chabert's vanga }}$} & & $E$ & \\
\hline Eleonora's falcon & Falco eleonorae & M & $\|$ & & $\frac{\text { Falculea palliata }}{\text { Leptopterus chabert }}$ & $E$ & \\
\hline Peregrine falcon & Falco peregrinus & B & । & \multirow{2}{*}{ Blue vanga } & \multirow{2}{*}{$\begin{array}{l}\text { Cyanolanius } \\
\text { madagascarinus }\end{array}$} & \multirow{2}{*}{ B } & \\
\hline Helmeted guineafowl & Numida meleagris & 1 & & & & & \\
\hline Madagascar buttonquail & Turnix nigricollis & E & & Crested drongo & Dicrurus forficatus & B & \\
\hline White-throated rail & Dryolimnas cuvieri & B & & Pied crow & Corvus albus & B & \\
\hline Madagascar turtle dove & Streptopelia picturata & B & & Common mynah & Acridotheres tristis & I & \\
\hline Namaqua dove & Oena capensis & B & & Madagascar starling & Hartlaubius auratus & $E$ & \\
\hline Madagascar green pigeon & Treron australis & $\mathrm{B}$ & & Sakalava weaver & Ploceus sakalava & $E$ & \\
\hline Greater vasa parrot & Coracopsis nigra & B & $\|$ & \multirow[t]{2}{*}{ Madagascar fody } & \multirow{2}{*}{$\begin{array}{l}\text { Foudia } \\
\text { madagascariensis }\end{array}$} & \multirow[t]{2}{*}{$E$} & \\
\hline Lesser Vasa Parrot & Coracopsis vasa & B & $\|$ & & & & \\
\hline Gray-headed lovebird & Agapornis cana & $E$ & $\|$ & Madagascar mannikin & Lonchura nana & $E$ & \\
\hline
\end{tabular}

\begin{tabular}{|l|l|l|l|}
\hline Madagascar lesser cuckoo & Cuculus rochii & $\mathrm{M}, \mathrm{B}$ & \\
\hline Crested coua & Coua cristata & $\mathrm{E}$ & \\
\hline
\end{tabular}

\begin{tabular}{|l|l|l|l|}
\hline Madagascar coucal & Centropus toulou & B & \\
\hline Western scops owl & Otus madagascariensis & E & ॥ \\
\hline
\end{tabular}

by Robinson et al. (2006), a total of 20 mammal species have been recorded within the Montagne des Français. However, four mammal species mentioned during the course of interviews were not recorded during the surveys: Grey bamboo lemur (Hapalemur griseus), Fosa (Cryptoprocta ferox), Indian civet (Viverricula indica), and African wild pig (Potamochoerus larvatus). They are thought to have been present within the massif until recently and may still be present at low population densities. Fosa (Cryptoprocta ferox) is listed as Endangered on the 2007 Red List of Threatened Species and Grey bamboo lemur (Hapalemur griseus) is considered as Critically Endangered by Mittermeier et al. (2006).

Several bird species observed are listed on CITES Appendix I or II (see Table 3) and are species that are subject to the international pet trade, such as birds of prey, lovebirds, and parrots (CITES 2007).

The Madagascar crested ibis (Lophotibis cristata) is hunted by $28 \%$ of the interviewees and is listed as near threatened on the 2007 Red List due to declining numbers as a result of, on one hand, the reduction and loss of area and quality of habitat in which it lives, and on the other hand due to hunting. The presence of Fulvous-whistling duck (Dendrocygna bicolor) and Squacco heron (Ardeola ralloides) is thought to be due to the proximity of mangrove habitat. The level of endemism of birds within the Montagne des Français (41\%) is unexceptional in a Malagasy context, i.e. relatively low, given that $51 \%$ of breeding bird species are endemic to the island (Hawkins and Goodman 2003).

Despite the anthropogenic pressures on the habitats within the Montagne des Français, the topography of the massif has afforded it some degree of protection while the matrix surrounding it has been degraded. The relatively small size of the Montagne des Français and its ecological insularity is a major cause for concern because the massif may 
no longer support viable populations of species with large home ranges such as Aye-aye (Daubentonia madagascariensis) and Fosa (Cryptoprocta ferox) (Ancrenaz et al. 1994). Connectivity with other semi-natural areas such as the dry forest at Orangea $8 \mathrm{~km}$ to the north (Figure 1) is desirable to allow the exchange of individuals within subpopulations (Hawkins and Racey 2005).

It is clear that whilst local households rely on natural resources for livelihoods, they are directly contributing to the degradation of the forest ecosystems of the Montagne des Français. Amongst others, charcoal production and cattle grazing seem to be the predominant threats within the massif. Charcoal is produced for personal use and for resale in Antsiranana and consequently many of the more accessible areas within the massif have been cleared for this purpose. Also, larger areas of the lower slopes have been cleared to enable zebu cattle to graze; zebus were observed by the authors penetrating as far as the base camp. The harvesting of wood for resale also has a detrimental effect on biodiversity but we think that the pressure from this activity may have eased since the area was selectively logged for valuable timber 30 years ago. The hydrology and topography of the massif are such that cultivation of rice and other crops is not an extensive activity and hence does not have a significant negative impact on the biodiversity of the massif.

Hunting is a widespread activity, which is a major pressure on the fauna of the massif with many bird and mammal species considered as potential targets. Five of the species (one bird and four mammals) currently hunted are listed on the 2007 Red List. According to our findings, the Madagascar crested ibis (Lophotibis cristata) seems to be present at very low population densities. Therefore we consider the hunting pressure to be great enough to extirpate this bird from the massif in the near future. On the other hand, a significant proportion of inhabitants do not hunt lemurs as it is considered fady, and as such the Montagne des Français has an important role to play in the conservation of lemurs in northern Madagascar.

Previous studies have proved that the Montagne des Français is an important centre of endemism for plants, invertebrates, amphibians and reptiles (Pintak and Böhme 1988, Glaw et al. 2001, Lavranos et al. 2001, Glaw et al 2005a,b, Andriamampianina et al. 2000, Lourenço and Goodman 2006, D'Cruze et al. 2007). The results presented in this paper along with those presented by Robinson et al. (2006) and D'Cruze et al. (2007) show that the Montagne des Français is an important biodiversity hotspot, and together they provide strong support to the case for permanent formal protection.

FURTHER INITIATIVES. In this section we suggest opportunities for conservation and development initiatives, which could enhance the protection of the biological diversity within the Montagne des Français through the alteration of patterns of natural resource use amongst the local community. Sustainability in conserving this area will only be achieved if the local communities are fully engaged in a participatory process, and if their livelihood is secured. Furthermore, the following modest list of initiatives shall also help the cause of recommending this region as a Permanent Protected Area:
- $\quad$ Development efforts to improve human health conditions through initiatives such as the provision of hygiene information and mobile health clinics;

- Implementation of conservation education at school and community level;

- Formulation of a long-term management plan for the massif involving the local communities, NGOs and ANGAP:

- Improvement of structural ecological connectivity with other semi-natural habitats such as Orangea $8 \mathrm{~km}$ to the north;

- Development of alternative forms of income for local communities such as community based ecotourism.

In addition, there are opportunities for further research into the biological resources of the massif. The following list of tasks could provide valuable support to the case for a Permanent Protected Area:

- Search for signs of Grey bamboo lemur (Hapalemur griseus) and Fosa (Cryptoprocta ferox);

- Identification of Eliurus sp. and Microgale sp.

- Identification of ring-tailed mongoose (Galidia elegans) to subspecies level.

\section{ACKNOWLEDGEMENTS}

We are grateful to the Ministère de I'Environnement, des Eaux et Forêts for permitting us to carry out our research and to the University of Antsiranana. Special thanks are also extended to our guides Edmond Randriamalala and Georges. We would also like to thank Enanatse Alfred, Onjaniaina Cecilia Paulariot, Achille Raselimanana, Philip Cowling, Natasha Calderwood, Despina Psarra, Kate Stout and to all the Frontier and University of Antsiranana staff and volunteers whose work and effort made this study possible.

\section{REFERENCES}

Ancrenaz, M., Lackman-Ancrenaz, I. and Mundy, N. 1994. Field observations of Aye-ayes (Daubentonia madagascariensis) in Madagascar. Folia Primatologica 62, 1-3: 22-36. (doi:10.1159/000156760)

Andriamampianina, L., Kremen, C., Vane-Wright, D., Lees, D. and Razafimahatratra, V. 2000. Taxic richness patterns and conservation evaluation of Madagascan Tiger beetles (Coleoptera: Cicindelidae). Journal of Insect Conservation 4: 109-128. (doi:10.1023/ A:1009667712512)

Cornet, A. 1974. Essai de cartographie bioclimatique à Madagascar. Notice explicative $N^{\circ} 55$. ORSTOM, Paris.

CITES. 2008. The CITES Appendices. <www.cites.org/eng/app/index> accessed 20 July 2008.

D’Cruze, N., Sabel, J., Green, K., Dawson, J., Gardner, C., Robinson, J., Starkie, G., Vences, M. and Glaw, F. 2007. The first comprehensive survey of amphibians and reptiles at Montagne des Français, Madagascar. Herpetological Conservation and Biology 2, 2: 87-99.

Glaw, F., Vences, M. and Schmidt, K. 2001. A new species of Paroedura Günther from northern Madagascar (Reptilia, Squamata, Gekkonidae). Spixiana 24, 3: 249-256.

Glaw, F., Franzen, M. and Vences, M. 2005a. A new species of Colubrid snake (Liopholidophis) from northern Madagascar. Salamandra 41: 83-90.

Glaw, F., Vences, M. and Nussbaum, R. A. 2005b. A new species of Heteroliodon (Reptilia: Squamata: Colubridae) from Montagne des Français, far northern Madagascar. Herpetologica 61, 3: 275-280. 
Goodman, S. M., Ganzhorn, J. U., and Rakotondravony, D. 2003. Introduction to the mammals. In: The Natural History of Madagascar. S. M. Goodman and J. P. Benstead (eds.), pp 1159-1186. The University of Chicago Press, Chicago.

Hawkins, A. F. A. and Goodman, S. M. 2003. Introduction to the birds. In: The Natural History of Madagascar. S. M. Goodman and J. P. Benstead (eds.) pp 1019-1044. The University of Chicago Press, Chicago.

Hawkins, C. E. and Racey, P. A. 2005. Low population density of a tropical forest carnivore, Cryptoprocta ferox: Implications for protected area management. Oryx 39, 1: 35-43. (doi:10.1017/S0030605305000074)

Herzog, S. K., Kessler, M. and Cahill, T. M. 2002. Estimating species richness of tropical bird communities from rapid assessment data. The Auk 119, 3: 749-769. (doi:10.1642/0004-8038(2002)119[0749:ESROTB]2.0.CO;2)

Humbert, H. \& Cours Darne, G. 1965. Carte internationale du tapis végétal et des conditions écologiques à 1/1.000.000. Notice de la carte de Madagascar. Travaux de la Section Scientifique et Technique de I'Institut Français de Pondichéry. Hors série 6: 1-165 (3 cartes).

IUCN 2007. 2007 IUCN Red List of Threatened Species. <WWW.iucnredlist. org > accessed 2 February 2008.

Lavranos, J., Röösli, W. and Hoffmann, R. 2001. Montagne des Français - an ultimate paradise in Madagascar. Cactus and Succulent Journal 73, 1 4-11.

Lourenço, W. R. and Goodman, S. M. 2006. Description of a new species of Heteroscorpion Birula, 1903 (Scorpiones, Heteroscorpionidae) from the Montagne des Français in extreme northern Madagascar. Zootaxa 1269: 31-41.

Mackinnon, S. and Phillipps, K. 1993. A Field Guide to the Birds of Borneo, Sumatra, Java, and Bali. Oxford University Press, Oxford.

Ministère de l'Environnement, des Eaux et Forêts. 2005. Troisième Rapport National de la Convention sur la Diversité Biologique. Programme des Nations Unies pour l'Environnement, Antananarivo.

Mittermeier, R. A., Konstant, W. R., Hawkins, F., Louis, E. E., Langrand, O., Ratsimbazafy, J., Rasoloarison, R., Ganzhorn, J. U., Rajaobelina, S. Tattersall, I. and Meyers, D. M. 2006. Lemurs of Madagascar. $2^{\text {nd }}$ Ed. Conservation International, Washington D. C.
O'Dea, N., Watson, J. E. M. and Whittaker, R. J. 2004. Rapid assessment in conservation research: a critique of avifaunal assessment techniques illustrated by Ecuadorian and Madagascan case study data. Diversity and Distributions 10: 55-63. (doi:10.1111/j.1472-4642.2004.00050.x)

Olivieri, G., Craul, M. \& Radespiel, U. 2005. Inventaire des lémuriens dans 15 fragments de forêt de la province de Mahajanga. Lemur News 10: 11-16.

Pintak, T. and Böhme, W. 1988. Mantella viridis sp. n. (Anura: Ranidae: Mantellinae) aus Nord-Madagaskar. Salamandra 24, 2-3: 119-124.

Ramanamanjato, J.-B., Nussbaum, R. A. and Raxworthy, C. J. 1999. A new species of Mabuya Fitzinger (Squamata: Scincidae: Lygosominae) from northern Madagascar. Occasional Papers of the Museum of Zoology, The University of Michigan 728:1-22.

Rasoloarison, R. M., Goodman, S. M. and Ganzhorn, J. U. 2000. Taxonomic revision of mouse lemurs (Microcebus) in the western portions of Madagascar. International Journal of Primatology 21, 6: 963-1019. (doi:10.1023/A:1005511129475)

Robinson, J. E., D'Cruze, N. C., Dawson, J. S. and Green, K. E. 2006. Bat survey in Montagne des Français, Antsiranana, northern Madagascar (6 April - 14 December 2005). African Bat Conservation News 9: 8-12.

Scheumann, M., Rabesandratana, A. and Zimmermann, E. 2007. Predation, communication, and cognition in lemurs. In: Primate Anti-predator Strategies. S. L. Gursky and K. A. I. Nekaris (eds.), pp 100-126. Springer, New York.

Stephenson, P. J. 1994. Seasonality effects on small mammal trap success in Madagascar. Journal of Tropical Ecology 10, 3: 439-444.

Trainor, C. R. 2002. Status and habitat associations of birds on Lembata Island, Wallacea, Indonesia, with reference to a simple technique for avifaunal survey on small islands. Bird Conservation International 12: 365-381. (doi:10.1017/S095927090200223X)

Watson, J. E. M., Whittaker, R. J. and Dawson, T. P. 2005. The importance of littoral forest remnants for indigenous bird conservation in southeastern Madagascar. Biodiversity and Conservation 14: 523-545. (doi:10.1007/s10531-004-3913-8) 